UDC 7:001.1

\section{Цитування:}

Арая Берріос Н. В., Шульгіна В. Д. Особливості здійснення соціокультурного проєктування на прикладі музично-циркового арт-проєкту «КОЛО». Вісник Наџіональної академї керівних кадрів культури $і$ мистецтв : наук. журнал. 2021. № 4. C. 140-144.

Araya Berrios N., Shulgina V. (2021). Social and cultural project aspects on the example of musical and circus art project "CIRCLE". National Academy of Culture and Arts Management Herald: Science journal, 4, 140-144 [in English].
Araya Berrios Nina,

Ph.D. of Arts, Assistant of Rector in Kyiv Municipal

Academy of Circus and Performing Arts;

ORCID: https://orcid.org/0000-0002-9878-8208

n.araya@kmaecm.edu.ua

Shulgina Valeria,

Doctor of art history, Professor in Kyiv Municipal

Academy of Circus and Performing Arts

ORCID: https://orcid.org/0000-0001-6007-2901

v.shylgina@kmaecm.edu.ua

\title{
SOCIAL AND CULTURAL PROJECT ASPECTS ON THE EXAMPLE OF MUSICAL AND CIRCUS ART PROJECT "CIRCLE"
}

The purpose of the article. Identify the background of social and cultural project aspects in modern European cultural integration in Ukraine based on the activities of the Kyiv Municipal Academy of Circus and Performing Arts; to outline the European integration vectors of performative cultural creation in Ukraine of the XXI century; to consider culture as a condition and a term of solving problems and tasks that are in other planes of social and individual life. The aim of the article is to analyze the musical and circus art project "Circle", which aims to combine and interact with traditional and innovative artistic trends by integrating them into a common and integral cultural area. The aim of the article is to analyze the music and circus art project "Circle", which aims is to combine and interact with traditional and innovative artistic trends by integrating them into a common and integral cultural space. The peculiarity of the work is the analysis of the phenomenon of "social and cultural project aspects", how it is reflected in the artistic area and how it affects culture in general. It is proved that in this context the starting point of cultural creation and formation of cultural norms and values is the activity of the educational institution, which affects the development of infrastructure and improvement of social and cultural space. Tasks: to identify the roots of social and cultural project aspects of modern European integration culture in Ukraine based on the activities of the Kyiv Municipal Academy of Circus and Performing Arts; to outline the European integration vectors of performative cultural creation in Ukraine of the XXI century; to consider culture as a condition and a means of solving problems and tasks that are in other planes of social and individual life. Methodology. The research is based on an interdisciplinary approach using the methods of historicism, scientific retrospection, personology, source study approach, and the method of theoretical generalization. The scientific novelty of the research is that the historical facts concerning the Kyiv Municipal Academy of Circus and Performing Arts, about its cultural and creative activity on the example of the music and circus art project "Circle" are collected and systematized. The significance of international collaboration for the further development of European integration processes in Ukraine of the XXI century is proved, the European integration cultural creation in Ukraine is investigated on the example of the music and circus art project "Circle". Conclusions. All-Ukrainian and international creative projects in the context of social and cultural project aspects are aimed at reproducing and preserving culture by internalizing cultural values, replicating the best ideas, attracting new technologies for cultural development in general as a basis for interpersonal and international communication. Creating and supporting art projects is one of the main tasks of cultural policy in educating the next generation of citizens with a clear cultural and national identity, which will further increase the cultural potential of the nation and the presentation of art projects in the international arena.

Keywords: European integration, social and cultural project aspects, musical and circus art project "Circle", international collaboration, Kyiv Municipal Academy of Circus and Performing Arts, musical art, circus art.

Арая Берріос Ніна В'ячеславівна, кандидат мистецтвознавства, помічник ректора Київської муніңипальної академії естрадного та циркового мистеитв; Шульгіна Валерія Дмитрівна, доктор мистецтвознавства, професор Київської муніципальної академії естрадного та циикового мистецтв

Особливості здійснення соціокультурного просктування на прикладі музично-циркового артпроєкту «КОЛО»

Метою статті $\epsilon$ проведення аналізу музично-циркового арт-проєкту «КОЛО», який має на меті поєднання і взаємодію традиційних та інноваційних мистецьких напрямків шляхом їх інтеграції в спільний та цілісний культурний простір. Особливість роботи полягає в аналізі феномену «соціокультурне проєктування», як воно

(CAraya Berrios N., 2021

CShulgina V., 2021 
відображається в мистецькому полі та як впливає на культуру загалом. Доводиться, що у даному контексті відправним моментом культуротворення і формування культурних норм та цінностей виступає діяльність освітнього закладу, яка впливає на розвиток інфраструктури та удосконалення соціально-культурного простору. Завдання роботи: виявити коріння соціокультурного проєктування сучасного євроінтеграційного культуротворення в Україні на основі діяльності Київської муніципальної академії естрадного та циркового мистецтв; накреслити євроінтеграційні вектори перформативного культуротворення в Україні XXI ст; розглянути культуру як умову та засіб вирішення проблем і завдань, які перебувають в інших площинах соціального й індивідуального буття. Методологія. Дослідження спирається на міждисциплінарний підхід 3 використанням методів історизму, наукової ретроспекції, персонології, джерелознавчого підходу та методу теоретичного узагальнення. Наукова новизна дослідження полягає в тому, що зібрані та систематизовані історичні факти стосовно Київської муніципальної академії естрадного та циркового мистецтв, про ії культурну та творчу діяльність, музично-цирковий арт-проєкт «Коло», зокрема. Доведено значимість міжнародної колаборації для подальшого розвитку євроінтеграційних процесів в Україні ХХІ ст., досліджується євроінтеграційне культуротворення в Україні на прикладі музично-циркового арт-проєкту «Коло». Висновки. Всеукраїнські та міжнародні творчі проєкти в контексті соціокультурного проєктування спрямовані на відтворення й збереження культури шляхом інтеріорізації культурних цінностей, на тиражування кращих ідей, залучення новітніх технологій для розвитку культури загалом як основи налагодження міжособистісної та міжнародної комунікації. Створення та підтримка мистецьких проєктів $є$ одним з головних завдань культурної політики стосовно виховання майбутнього покоління громадян 3 чітко визначеною культурною та національною ідентичністю, що забезпечить подальше зростання культурного потенціалу нації та презентації мистецьких проєктів на міжнародній арені.

Ключові слова: євроінтеграція, соціокультурне проєктування, музично-цирковий арт-проєкт «КОЛО», міжнародна колаборація, Київська муніципальна академія естрадного та циркового мистецтв, музичне мистецтво, циркове мистецтво.

Relevance of the research topic. The relevance of the research topic is to analyze the phenomenon of "social and cultural project aspects ", how it is reflected in the sphere of art and how it affects culture in general. It is proved that the starting point of accurate cultural creation and formation of cultural norms and values is the activity of the educational institution, which affects the development of infrastructure and improvement of social and cultural space. The deepening of international processes of culture development in Ukraine in the XXI century is due to the establishment of a national vector for Europeanization, support and promotion of achievements in culture and art at the world level, implementation of international projects, and the possibility of quality art education and training in Europe.

Analysis of publications. The basic fundamental principles of social and cultural projecting were developed by scientists like J. Ditrich, T. Tiori, D. Fry, P. Hillosch, and other researchers. In the post-Soviet time, the first ideas about the design of social systems were expressed in the works of O. Genisaretsky, V. Dubrovsky, I. Lyakhov, A. Rappoport, V. Rozin, B. Sazonov, G. Shchedrovitskiy. From the point of view of social management, these problems were considered by V. Afanasyev, I. Bestuzhev-Lada, P. Lebedev. Actually, the theoretical foundations of social project aspects were analyzed in the works of $\mathrm{N}$. Aitov, G. Antonyuk, N. Lapin, A. Pryhozhyn, J. Toshchenko, N. Kharitonov, as well as in the studies of Y. Kryuchkov, O. Yanitsky, and others. Very interesting are publications about the development of theoretical and methodological foundations of social-cultural projecting of such scientists as G. Birzhenyuk, S. Zuev, A. Markov, E. Orlova, and others. The theory and methods of social-cultural project aspects need modern research in the context of European integration processes [1].

Presenting of the main material. A big event had happened on June 26 and 27, 2021 at Lviv State Circus - a presentation of the musical and circus art project "Circle", organized by the Kyiv Municipal Academy of Circus and Performing Arts. This is a great example that shows the development and influence on the formation of social and cultural project aspects.

Let's analyze the creative way and activity of the Academy in the context of international cooperation. In 2021, the Kyiv Municipal Academy of Circus and Performing Arts celebrated its 60-th anniversary. This is a long and difficult journey from the chamber Republican studio, which was started by the Yalovi brothers in the rooms of today's National Circus of Ukraine in 1961. Inspired by a love for their profession, Vasyl and Oleksandr Yalovi began to promote circus art very active way - acrobatics, gymnastics, balance, and other not only circus genres: master of ceremonies, singing, and choreographic. Back then, they understood that art is an opportunity to look behind the "iron curtain", to demonstrate their talents and high 
professionalism of their country at the world level. As children, the future legendary artists played in their backyard - pulling the ropes, doing handstands and other acrobatic tricks, this principle of "learning through playing", the brothers will actively use in the building of the educational process of future circus artists [2].

So, the first step has been taken - opening the space for developing professional skills and knowledge. L. Bogdanovich, director and artistic director of the Ukrkoncert touring and concert association, and Yukhima Berezin and Yuriy Tymoshenko, a well-known "Tarapunka \& Shtepsel" comedian duo of Ukrainian actors, also joined the process of creating a republican studio. The team of people who has the same ideas and believes started to create the history of the Academy, which we know now. [2] It is important to note that the approaches of multidisciplinary classes are used by the modern Academy even nowadays. After all, it was important for students to develop comprehensively in order to become creative and extraordinary artists. That is why, in addition to the main disciplines, students studied acting and stage language, history of theater, circus and performing, makeup, choreography, stage movement, and fencing, as well as piano, solfeggio, music theory, and music literature. The formation of the actor's personality took place on the physical and emotional levels - this was the key to success; a high-quality educational process gave a high result of the preparation of acts and presentations in various parts of the Soviet Union and international prestigious arenas.

1975 was a remarkable year for the school, as the Studio got a different status - the Kyiv State School of Performing and Circus Arts, which at the time was subordinated to the Ministry of Culture of the USSR. Two departments are created on the basis of the school: performing and circus. Approximately the same principle of distribution is preserved in the Academy today. Nurturing traditional approaches to training future artists, the "performing department" trained artists of the conversational genre, choreography, singing, and other different original genres, the "circus department" conducted training in the following genres: clowning, acrobatics, juggling, aerial gymnastics, and others.

Since 1999, the College has become an active participant in all big cultural and art events of the capital of Ukraine, Kyiv city. During these years the tradition of annual grand graduation gala shows of students begins, which is free for everyone to visit.

In 2002, during the term of directing by Alexander Chunikhin (1998-2011), the college moved to its own building at the address - 01032, Kyiv, 88 Zhylyanska Str.

Since 2007 it has officially received the status of a higher educational institution Academy. It was a great time for the Academy, the basic educational form of study is engraved bachelor's degree in specialties: dolls on the stage, dancing, singing, masters of ceremonies, actors, musical eccentricity, pantomime, and other circus genres [2].

From 2011 to 2019, the head of the Academy became Honored Artist of Ukraine, Ph.D. of Art History, Doctor of Cultural Studies, Professor Vladyslav Kornienko. It was him who initiated new specializations, opened a master's degree and a part-time studying and initiated the studying process for foreign students.

In 2019, Professor, Doctor of Cultural Studies, Associate Professor Alexander Yakovlev became the Rector of the Academy. His personal contribution to the promotion of the Academy at the international level is due to his creative collaboration with "Festival international du cirque de Monte-Carlo 2020", "Global Alliance of Circus Schools", Capital Circus of Budapest, School of Circus Arts by Imre Barosh, Budapest, Hungary and other domestic public and cultural organizations, such as Kyiv Academic Drama and Comedy Theater on the left bank of the Dnieper, Kyiv National Academic Operetta Theater, Kyiv Academic Theater "Golden Gate", National Circus of Ukraine, Lviv State Circus, etc. The Ministry of Education of the People's Republic of China has included the Kyiv Municipal Academy of Circus Performing Arts in the list of higher education institutions for professional cooperation in the educational process. For the first time, the Academy establishes its scientific publication "ART-PLATFORM", which is a logical step for further deeper scientific activities and the opening of graduate school to train specialists of the highest academic level - "Doctor of Philosophy" and "Doctor of Arts" [2].

Analyzing the educational and cultural activities of the higher education institution, the leadership of the Academy constantly asked itself the question - how to promote the performing and circus arts among the audience more widely. An ambitious decision was made to go on a city tour - to perform each annual gala show in a new city of Ukraine, this involved more and more people into the interaction between cultural and social aspects, which takes place at the level of the individual, social community, region, district, and society.

This Summer, for the Ukrainian audience, if you want to see the best examples of world circus 
and performing arts, it was no longer necessary to go to the performance of the circus Du Soleil, because all this could be seen in your city or traveling around Ukraine. 70 professional artists in one time and space demonstrated different styles - acrobatics, gymnastics, balance, pantomime, clowning, magic, puppetry, singing, choreography, and acting.

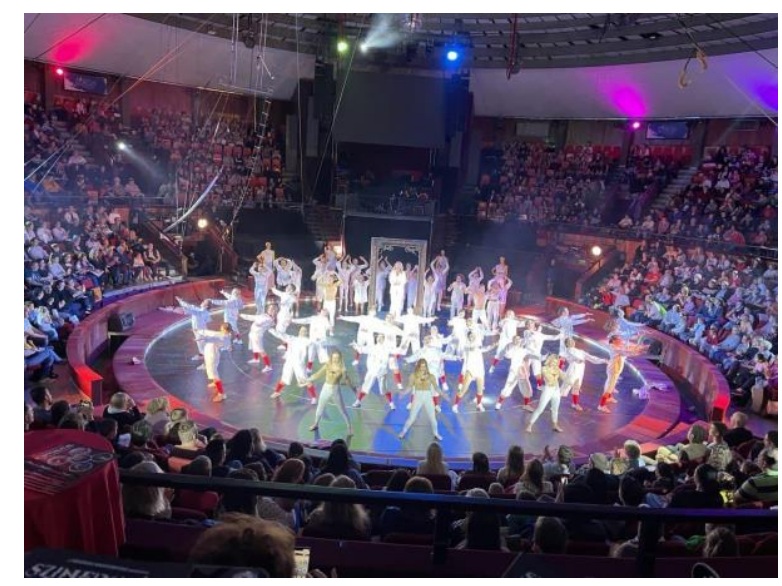

Fig.1 Fragment of a performance from the show "Circle" in Lviv

The invited celebrity participant of the show was Alina Pash. The Ukrainian singer, rapper, finalist of the sixth season of the vocal show "XFactor", a former student of the Academy, specially came to perform on the show and present her new song.

The general director of the show was the famous Iryna Herman. The whole circus world knows about her achievement. She is a real celebrity in circus directing. Irina received awards personally from the Princess of Monaco for participation and collaboration with the International Circus Festival in Monte-Carlo. For more than 24 years she has been cooperating with leading circus companies around Europe and the world: National Swiss Circus Knie (Switzerland), Roncalli circus (Germany), Bouglione circus (France), Krone circus (Germany), Vazquez circus (USA), GOP variety, Apollo variety, Winter Garten variety, Friedrichsbau variety (Germany). Her work has been awarded 12 prizes at the world's most prestigious international circus festival in Monte-Carlo, including 2 bronze clowns $(2003,2020)$ and 2 special jury prizes (2008 and 2012).

Honored foreign guests of the show in Lviv were:

Mr. Urs Pils - Vice President and Artistic Director of the International Circus Festival in Monte Carlo, President of the World Circus Federation (Fédération Mondiale du Cirque),
President of the European Circus Association (ECA).

Mr. Peter Fekete - the Minister of State of Culture of Hungary, a member of the Executive Board of the European Circus Association (ECA).

As a result of a productive presentation of the show "Circle", the Minister of State of Hungary, Mr. Peter Fekete, invited the Kyiv Municipal Academy of Circus and Performing Arts to demonstrate this great show at the building of the Budapest Capital Circus. This invitation was a great honor for the Academy and at the same time a challenge, because the Academy has never traveled abroad before and with such a large number of people - 75 people, among them 60 artists and 15 people of the pedagogical and administrative group.

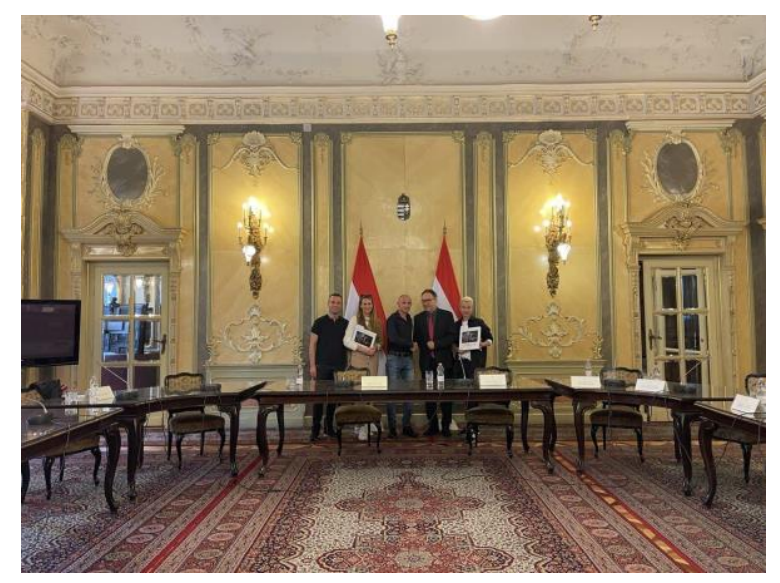

Fig.2. Collective photo with the Minister of Culture of Hungary - Peter Fekete, Rector of the Kyiv Municipal Academy of Pop and Circus Arts Alexander Yakovlev, director of the show "Circle" - Irina Herman, technical director of the show "Circle" - Igor

Protsenko, assistant rector of the Academy of Kyiv circus arts Nina Araya Berrios

The preparatory process lasted two months daily rehearsals, updating the repertoire and cast. The base for training was the cultural center "ArtBratislava", which was specially rented for making the show.

On October 9 and 10, 2021, the show "Circle" took place in the city of Budapest, directed by Iryna Herman, full of visitors, spectacular act,s and a festive atmosphere. The Academy presented itself with dignity in the international arena and demonstrated not only the high level of the educational institution but also Ukraine as a powerful, experienced representative of the performing arts. 


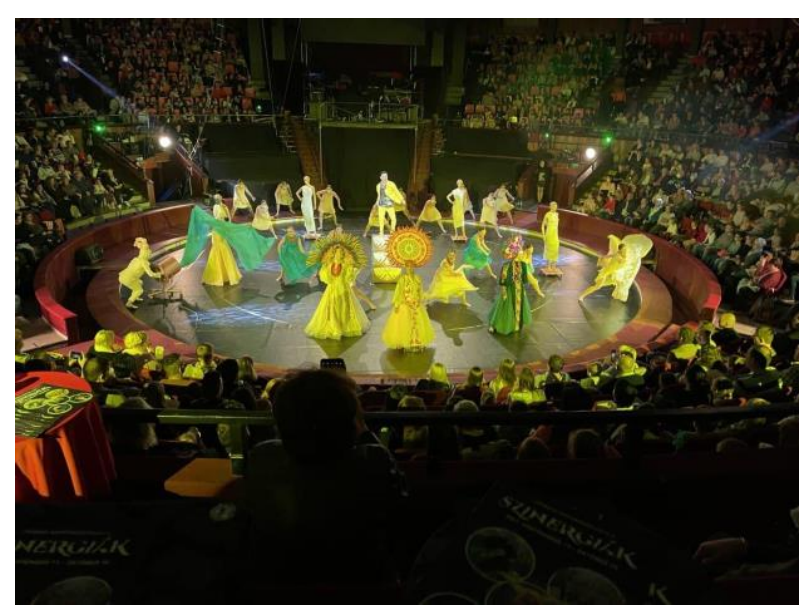

Fig.3. Excerpt from the performance of the show "Circle" in Budapest

It is important to note that this international project would not have taken place without the support and involvement of such partners as:

- Ministry of Culture of Hungary

- Department of Culture of the Kyiv City State Administration

- Capital Circus of Budapest

- School of Circus Arts by Imre Barosh, Budapest, Hungary

- Ministry of Foreign Affairs of Ukraine

- Embassy of Ukraine in Hungary

- Embassy of Hungary in Ukraine

Conclusions. Considering all the above, we can conclude that such national and international creative works in the context of social and cultural project aspects are aimed at reproducing and preserving culture by internalizing cultural values, replicating better ideas, attracting new technologies for cultural development in general as a basis for the interpersonal and international development of communication.

Creating and supporting art projects is one of the main tasks of cultural policy in educating the next generation of citizens with a clear cultural and national identity, which will further increase the cultural potential of the nation and the presentation of art projects on the international stage.

\section{Jimepamypa}

1. Івановська Н., Яковлев О., Шульгіна В. Соціокультурне поєктування в мистецтві: теорія та практика. Київ: НАКККіМ, 2018. 193 с.

2. КМАЕЦМ - історія. URL: https://kmaecm.edu.ua/istoriya (дата звернення: 05.11.2021).
3. Курбатов В., Курбатова О. Социальное проектирование: учеб. пособ. Ростов-на-Дону: Феникс, 2001. 416 с.

4. Россошанская О., Журавлева Н. «Проект» и «проектирование» как базовые категории комплексного подхода в социокультурной деятельности // Управління проєктами та розвиток виробництва: зб. Наук. Пр. Луганськ: Вид-во СНУ ім. В.Даля, 2009. №3(31). С. 168.

5. Синергетична парадигма простору культури: монографія до 50-річчя науковопедагогічної діяльності Валерії Шульгіної. Київ: НАКККіМ, 2014. 398 c.

6. Чернець В. Україна: динаміка культуротворчих процесів: [монографія]. Київ: ДАКККіМ, 2002. С. 175.

7. Яковлев О. Зміст соціокультурного проєктування в інформаційну добу: досвід Національної академії керівних кадрів культури і мистецтв // Культура України. Серія: Культурологія: зб. наук. пр. Харків: ХДАК, 2016. Вип. 52. С. 201 - 212.

\section{References}

1. Ivanovska N., Yakovlev O., Shulhina V. (2018). Socio-cultural designing in art: theory and practice. Kyiv: NAKKKiM. [in Ukrainian]

2. KMAETsM - history. URL: https://kmaecm.edu.ua/istoriya (data zvernennia: 05.11.2021).

3. Kurbatov V., Kurbatova O. (2001). Social design: textbook. Rostov-on-Don: Fenyks. 416. [in Russian]

4. Rossoshanskaia O., Zhuravleva N. (2009). "Project" and "design" as basic categories of an integrated approach in socio-cultural activities. Project management and production development: coll. of science. works. Lugansk: Publishing house SNU im. V. Dalia. №3(31). [in Russian]

5. Synergetic paradigm of cultural space: monograph to the 50th anniversary of scientific and pedagogical activity of Valeria Shulhina. Kyiv: NAKKKiM, 2014. 398. [in Ukrainian]

6. Chernets V. (2002). Ukraine: dynamics of cultural processes: monograph. Kyiv: DAKKKiM [in Ukrainian]

7. Iakovlev O. (2016). The content of sociocultural design in the information age: the experience of the National Academy of Culture and Arts Management. Culture of Ukraine. Series: Culturology: coll. of science. work. Kharkiv: KhDAK.Issue 52. 201 -212 pp. [in Ukrainian]

Стаття надійшла до редакиії 09.09.2021 Отримано після доопрацювання 11.10.2021 Прийнято до друку 18.10.2021 